\title{
Emergency Medical Management for Education Innovative Applications in Dealing with Tsunami Disasters
}

\author{
https://doi.org/10.3991/ijim.v15i08.21577 \\ Syamsul Bachri, Alfian Eko Prastyo ( $₫)$, Yudi Tri Harsono, \\ Muhammad Iqbal Akbar, Khaidir Rahman \\ Universitas Negeri Malang, Malang, Indonesia \\ alfianeko01@gmail.com
}

\begin{abstract}
In 2018 until 2019 there were three events, namely tsunami in Banten, Lampung and Central Sulawesi Provinces. The total death toll in the tsunami reached 3,754 and the number of victims suffering injuries amounted to 18,493 . One effort that can be implemented to minimize this impact is to develop an Android-based emergency medical disaster response application for Communities Residing in Tsunami Prone Areas. The application was developed with fifth stages that are emphatize, define, ideate, prototype, testing. The first stage includes interviews and gathering information about problems that occur in area disaster. The define stage includes formulating problems that occur in the field and trying to solve those problems with solutions. At the Ideate stage the system architecture is designed using UML design and User Interface design. Furthermore, a prototype design was made which was adjusted to the results of the analysis carried out in the previous stage. The testing phase includes the results of the test material, Usability and Functionality suitability show that the application of emergency medical disaster's response has eligible to be implemented in communities in areas prone to tsunami natural disasters. With the breakdown of the Usability testing results reached $86.3 \%$, and the Functionality Suitability testing reached $100 \%$, and the material test results reached $100 \%$. This application use for improving an education Tsunami disaster response based on problem and creative thinking.
\end{abstract}

Keywords - Emergency medical management, tsunami disaster, problem and creative thinking

\section{Introduction}

Natural disaster mitigation efforts have been made in recent years in high-risk countries affected by natural disasters, such as Japan, the United States, Chile, New Zealand, and Indonesia [13]. The system of preparedness for earthquake and tsunami hazards needs to be improved to reduce the economic and social impacts of potential earthquake events in the future [24]. Among several countries prone to tsunamiaffected natural disasters, Indonesia is in one of the most active zones, with 34 major 
events that have the potential to cause tsunami natural disasters in the past 20 years [14]. In 2018 until 2019 there were 3 tsunami natural disaster events in Indonesia, namely tsunamis in Banten, Lampung and Central Sulawesi Provinces. The total death toll in the tsunami reached 3,754 and the number of victims suffering injuries amounted to 18,493 [4]. The factors that can cause natural disasters cause many victims, namely the lack of information and early warning which causes unpreparedness, and the inability to face the threat of danger [17]. This fact makes the presentation of information about preparedness for natural disasters important, and the safety of victims of the tsunami disaster requires proper and quick help. This is important to be done to prevent a greater impact on victims. Today to get fast and accurate information about natural disaster warnings and post-natural disaster reporting is done manually by the officer in charge. This will take time and energy and less effective because not all people get the information and cannot report themselves when a natural disaster occurs.

Application development research related to natural disaster mitigation has been carried out with case studies of flood alert in the Mushim River Basin in Korea. Azam, et al [3] research results show that the development of the application can be used as a recommendation for the government to take further action to send information to the public. In addition, application development research related to natural disaster mitigation has been carried out with case studies of tsunami natural disaster evacuation using mobile applications. The research results of [15] showed that the development of the application was useful for tsunami victims to receive recommendations on where to go when the tsunami struck.

Based on the above background, we need a system to provide warnings to the community and report the situation after a natural disaster occurs. Information will be made in the system for how to deal with tsunami natural disasters, reporting the condition of disaster victims if medical assistance is needed in the form of physical or non-physical injuries, as well as the latest location reporting so that officers can find the last location of victims to be rescued. So the researchers intend to conduct research and development entitled "Development of Android-Based Emergency Medical Disaster Response Applications for Communities in Areas Prone to Tsunami Natural Disasters".

\section{Method}

\subsection{Research and development models}

The research and development model used in this development uses a procedural model. The procedural model describes the flow or steps that are followed to produce an emergency medical disaster response application. The design model used in this study is the design thinking development model. Design Thinking is a method of solving problems that focus on the user or user to make prototypes, provide comments, and redesign [18]. Design Thinking has five stages of the process carried 
out from the beginning of development to the product of the development, these are the following stages: (1) Emphatize, (2) Define, (3) Ideate, (4) Prototype, (5) Testing.

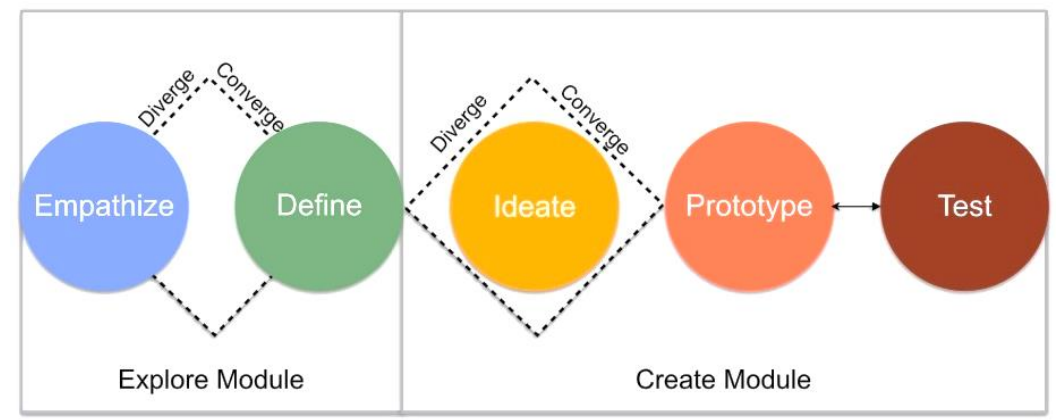

Fig. 1. Model Design Thinking

\section{Emphatize}

First stage of Design Thinking is emphatize. The benefit of this emphatize phase is to find out the experiences, emotions, and situations of the user. After the researcher analyzed the user's condition and the surrounding environment, the researcher conducted a literature study and interviews with several volunteers from IPPMST (Central Sulawesi Youth and Student Association) Malang, as well as the community in Srigonco Village, Bantur District, Malang Regency. It aims to extract a number of concrete data and information in the field relating to the handling of victims of the tsunami disaster, so that an overview is obtained to find out the problems and desires of potential system users.

\section{Define}

After researchers understand the needs of users, then researchers need to find a solution to the user problems that will be the basis of the product or application to be made. This can be done by making a list of user needs and using knowledge about the conditions that are happening. Researchers found several things including the following: (1) Lack of information about education on how to deal with the natural disaster of the tsunami (2) At the time after the disaster occurred, in the data collection of victim is still done manually (3) Slow in responding to report from the public who need medical assistance (4) Communities affected by the tsunami natural disaster require quick and effective treatment.

\section{Ideate}

With existing needs, the researcher needs to describe the solution needed. At this stage, researchers design the Medical disaster response application in accordance with the results of the previous analysis. At this stage the problem-solving description described previously is described by the author through the Unified Modeling Language (UML) in the form of a use case diagram. 


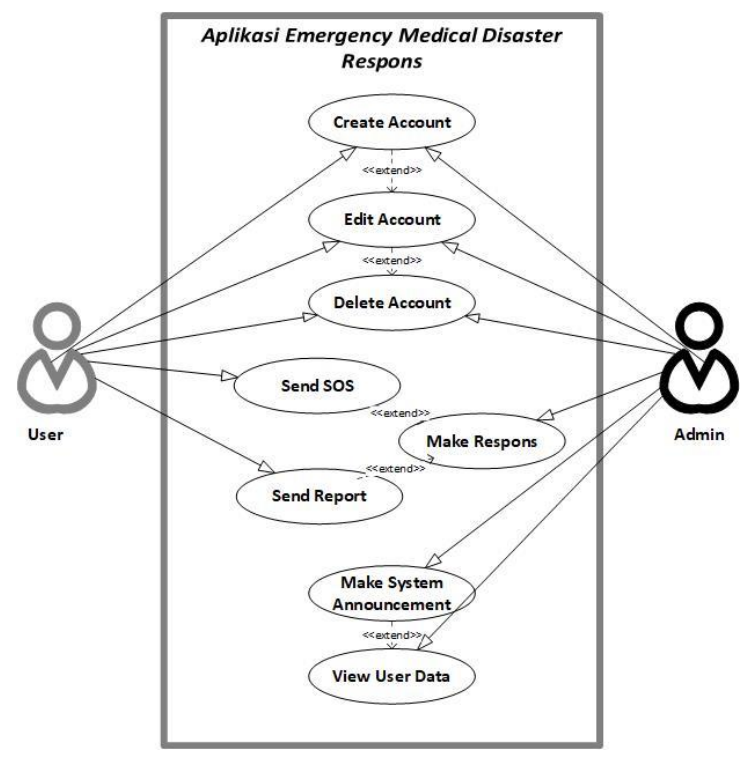

Fig. 2. Unified Modeling Language (UML)

\section{Prototype}

Pre-existing ideas need to be directly implemented in an application. A real application needs to be generated and a solution to the problems that are in the previous stage. Following is a prototype of the emergency medical disaster response application in the form of a user interface. Display user interface (User interface) is a communication mechanism between the user (user) with the system. The user interface can receive information from the user (user) and to provide information to the user to help directing the search for problems until a solution is found [19]. The Interface Design of the Medical disaster mobile apps includes splash screen design, registers and sign-ins and the main menu interface.

\section{Testing}

The testing phase is the stage that determines the feasibility of applications that have been developed. Tests carried out referring to the ISO 25010 standard criteria which include functional suitability and usability. In addition, the test criteria are also carried out with validation of material related to the contents of the material in the application made by medical experts. Testing the functional suitability aspect is done by the test case method of application functions by a software expert. The use ability aspect test was filled out by application users using a questionnaire instrument from [11]. 


\section{Results and Discussion}

\subsection{System implementation results}

At this stage, is the results of an Emergency Medical Disaster Response Mobile Apps. The software used to create the application is Android Studio. The software uses java programming language for logic and $\mathrm{xml}$ for user interface. The application product developed is a mobile app that can be run on smartphones with the Android operating system. Following are the results of the implementation.

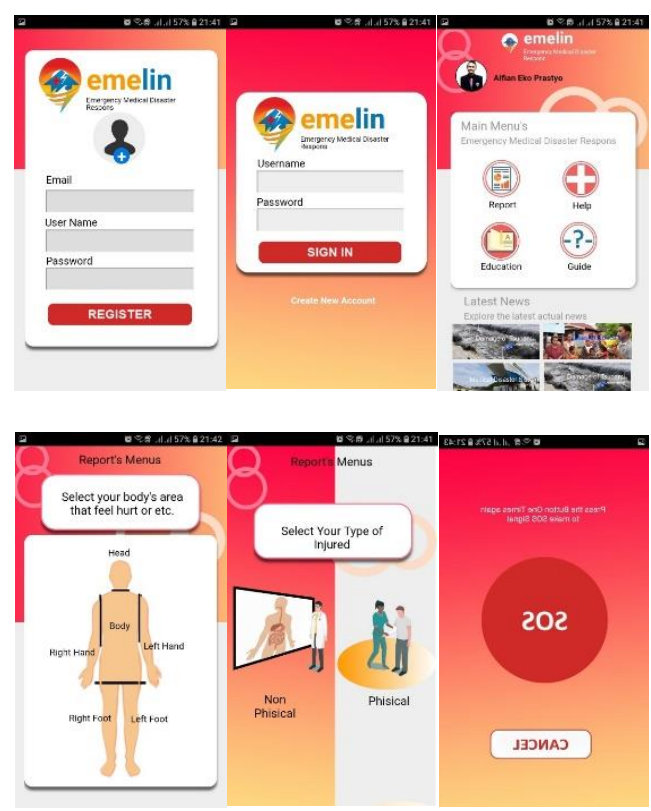

Fig. 3. System Implementation Results

\subsection{Application trial results}

After going through the application trial process which includes testing functionality suitability, usability and material testing. The test results are as follows.

1. Data functionality suitability testing

DataTesting functionality suitability is done using a checklist questionnaire filled out by software experts. The results of functionality suitability testing are as follows.

Based on the table above, it can be seen the percentage of each test item is as follows.

$$
\mathrm{YES}=\frac{20}{20} \times 100 \%=100 \%
$$




$$
\text { NO }=\frac{0}{20} \times 100 \%=0 \%
$$

Based on the analysis results of the calculations in the above table, then obtained the percentage of $100 \%$ for testing functionality suitability by software experts. The percentage results are then converted to a qualitative value based on the percentage of eligibility scale. Based on the results of the conversion of these values, testing functionality suitability is included in the "Very Eligible" category. The test results show that the functions contained in the Emergency Medical Disaster Response application are very feasible to use.

\section{Usability testing data}

The application was tested to people who live in areas prone to tsunami disasters precisely in Srigonco Village, Bantur District, Malang Regency. The data obtained is the product assessment by the user in the form of questionnaires as many as 19 questions with 4 scale answers. The questions in the questionnaire included aspects of operability, learnability, appropriateness recognizability, user interface aesthetics. Based on data obtained from 20 user response tests it is known that the ideal maximum score is 80 , the ideal minimum score is 20 , the ideal mean score is 50 , and the ideal standard deviation score is 10 .

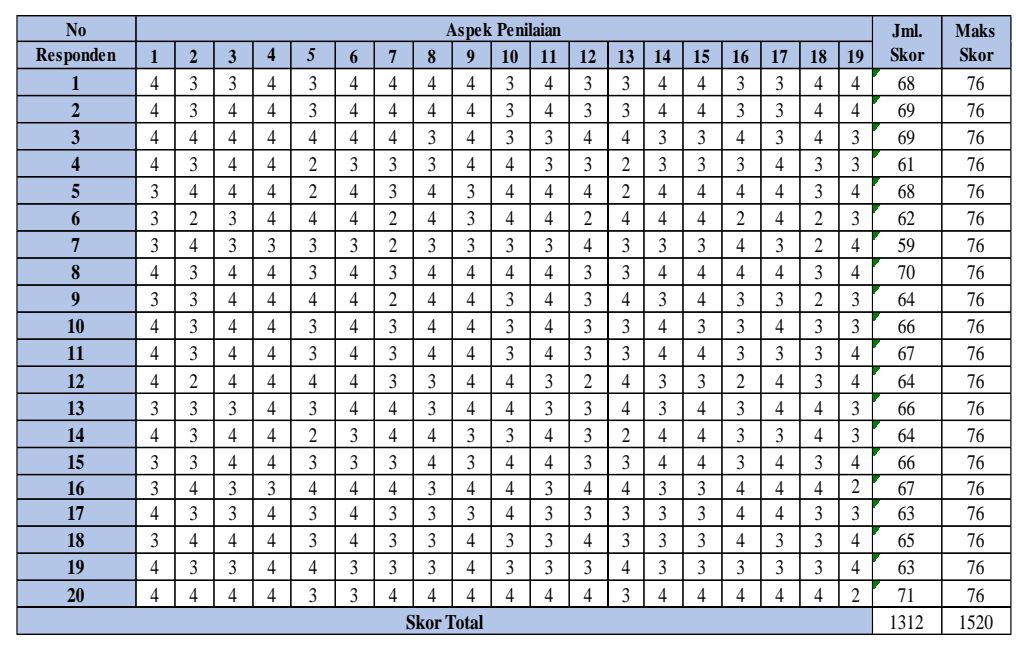

Fig. 4. Usability Testing Data

Based on the summary of test results, the following eligibility percentage can be obtained.

$$
\begin{gathered}
\text { Persentase Kelayakan }(\%)=\frac{\Sigma \text { Skor yang diobservasi }}{\Sigma \text { Skor yang diharapkan }} \times 100 \% \\
=\frac{1312}{1520} \times 100 \%=86,3 \%
\end{gathered}
$$


The result of the feasibility calculation was $86.3 \%$. The percentage results are then converted to qualitative values. Based on the results of the conversion of these values, usability testing is included in the "Very Eligible" category.

\section{Material test data}

Health material testing is carried out by experienced medical experts to assess the content of instructions or medical terms that are in the emergency medical disaster response application.

Based on the material test, it can be seen the percentage of each test item is as follows.

$$
\begin{gathered}
\text { YES }=\frac{10}{10} \times 100 \%=100 \% \\
\text { NO }=\frac{0}{20} \times 100 \%=0 \%
\end{gathered}
$$

Based on the analysis results of the calculations in the above table, then obtained a percentage of $100 \%$ for testing the material by medical experts. The percentage results are then converted to a qualitative value based on the percentage of eligibility scale. Based on the results of the conversion of these values, medical mater testing is included in the "Very Eligible" category. The test results show that the medical information contained in the Emergency Medical Disaster Response application is very feasible to implement.

\section{Conclusion}

Based on the results of the analysis and discussion of the data, the author obtained conclusions that can be drawn from research on the Development of Android-Based Emergency Medical Disaster Response Applications for Communities Located in Tsunami Prone Areas as follows:

The development of emergency medical disaster response application was developed through several stages, namely emphatize, define, ideate, prototype, testing. The emphatize stage includes interviews and gathering information about problems that occur in the field. The define stage includes formulating problems that occur in the field and trying to solve those problems with solutions. At the Ideate stage the system architecture is designed using UML design and User Interface design. UML design is illustrated by use case diagrams and activity diagrams. Furthermore, a prototype design was made which was adjusted to the results of the analysis carried out in the previous stage. The results of this design are then implemented into application development. The testing phase includes the product testing phase by implementing the application to the user and expert validation.

The results of the material test, Usability and Functionality Suitability show that the application of emergency medical disaster response can minimize the risk of the impact of the tsunami disaster, this is evidenced by all the results of the test getting the title "Very Eligible". 


\section{$5 \quad$ References}

[1] Akbar, S. (2013). Instrumen Perangkat Pembelajaran. Bandung: PT. Remaja Rosdakarya.

[2] Agustina, C., \& Wahyudi, T. (2015). Aplikasi Game Pendidikan Berbasis Android Untuk Memperkenalkan Pakaian Adat Indonesia, 1(1), 1-8

[3] Azam, M., Kim, H. S., \& Maeng, S. J. (2017). International Journal of Disaster Risk Reduction Development of $\mathrm{fl}$ ood alert application in Mushim stream watershed Korea. International Journal of Disaster Risk Reduction, 21(November 2016), 11-26. https://doi.org/10.1016/j.ijdrr.2016.11.008

[4] Badan Koordinasi Nasional Penanganan Bencana. (2009). Pengurangan Risiko bencana.Perum Percetakan Negara RI

[5] Eko, J. (2013). Koleksi Buku 2013 Pemograman SmartPhone menggunakan SDK Android dan Hacking Android / Jazi Eko Istiyanto, 2013.

[6] Flint, C. G. (2015). Community Emergency Response Teams: From Disaster Responders to Community Builders, (January 2006).

[7] Horspool, N., Pranantyo, I., Griffin, J., Latief, H., Natawidjaja, D. H., Kongko, W., Bustaman, B. (2014). A probabilistic tsunami hazard assessment for Indonesia, 1, 31053122. https://doi.org/10.5194/nhessd-2-3423-2014

[8] Hussein Tuama Hazim, Hasanain Abbas Hasan Al-Behadili, et.al. Design of Mobile Communication System for Emergency Services. iJIM - Vol. 14, No. 13, 2020. https://doi.org/10.3991/ijim.v14i13.14623

[9] Joshi, A., \& Pal, D. K. (2015). Likert Scale: Explored and Explained Likert Scale: Explored and Explained, (January). https://doi.org/10.9734/bjast/2015/14975

[10] Kafle, S. K. (2014). Community-Based Disaster Risk Management for Local Authorities Participant' S Workbook Asian Disaster Preparedness Participant S Workbook Community-Based Disaster Risk Management, (September)

[11] Lewis, J. (1995). IBM Computer Usability Satisfaction Questionnaires. International Journal of Human-Computer Interaction, 57-58. https://doi.org/10.1080 $\underline{10447319509526110}$

[12] Mahmoud Al-dalahmeh. The Viability of Mobile Services (SMS and Cell Broadcast) in Emergency Management Solutions: An Exploratory Study. iJIM - Vol. 12, No. 1, 2018 https://doi.org/10.3991/ijim.v12i1.7677

[13] Mueller, C., Power, W., Fraser, S., \& Wang, X. (2017). Journal of Geophysical Research: Solid Earth, 488-502. https://doi.org/10.1002/2014JB011301.Received

[14] Muhammad, A., Goda, K., Alexander, N. A., Kongko, W., \& Muhari, A. (2017). Tsunami evacuation plans for future megathrust earthquakes in Padang, Indonesia, considering stochastic earthquake scenarios, 2245-2270. https://doi.org/10.5194/nhess-2017-75

[15] Nik Nadian Nisa Nik Nazli, Sapora Sipon and Norita Md Norwawi. One Stop Center for Disaster Training Information in Smartphone Platform: A Mobile Prototype. iJIM Volume 9, Issue 4, 2015. https://doi.org/10.3991/ijim.v9i4.4418

[16] Pressman, Roger S. (2010). Rekayasa Perangkat Lunak: Pendekatan Praktisi (Buku Satu). Yogyakart: Andi Offset.

[17] Rahayu, Chrisdianto Agus. (2017). "Pengembangan Aplikasi Mobile Rescue Tentang Pertolongan Pertama Pada Kecelakaan Berbasis Geolokasi”. Malang:FT UM

[18] R., \& Shute, V. (2014). What Is Design Thinking and Why Is It Important? (May). https://doi.org/10.3102/0034654312457429

[19] Report, T., \& Lewis, J. R. (2014). IBM Computer Usability Satisfaction Questionnaires: Psychometric Evaluation and Instructions for Use, (January 1993). https://doi.org/10. $\underline{1080 / 10447319509526110}$ 
[20] Santoso, I. (2010). Pengembangan Aplikasi Penerjemah Bahasa Indonesia-Bahasa Jawa Pada Platform Berbasis Android. Jogjakarta: FT UNY.

[21] Scaling, G. (2010). 1 Introduction 2 An example of a perfect Guttman scale, 1-5.

[22] Simarmata, J. (2010). Rekayasa Perangkat Lunak. Yogyakarta: Penerbit AND

[23] Sugiyono. (2012). Metode Penelitian Pendidikan (Pendekatan Kuantitatif, Kualitatif, dan R\&D). Bandung: CV ALFABETA.

[24] Wood, N. J., \& Schmidtlein, M. C. (2016). Anisotropic path modeling to assess pedestrianevacuation potential from Cascadia-related tsunamis in the US acific orthwest, 275-300. https://doi.org/10.1007/s11069-011-9994-2

\section{Authors}

Syamsul Bachri is a Lecturer at the Geography Department, Faculty of Social Science, Universitas Negeri Malang.

Alfian Eko Prastyo is a Student at the Electrical Engineering Department, Faculty of Engineering, Universitas Negeri Malang. Email: alfianeko01@gmail.com

Yudi Tri Harsono is a Lecturer at the Faculty of Psychology Education, Universitas Negeri Malang.

Muhammad Iqbal Akbar is a Lecturer at the Electrical Engineering Department, Faculty of Engineering, Universitas Negeri Malang.

Khaidir Rahman is a Lecturer at the Vocational Education Department, STMIK AKBA Makassar, Indonesia.

Article submitted 2021-02-13. Resubmitted 2021-03-12. Final acceptance 2021-03-15. Final version published as submitted by the authors. 